\title{
THE EFFECT OF CHLORAMPHENICOL AND COPPER ON THE CELL ULTRASTRUCTURE OF SCENEDESMUS SP.
}

\author{
Olfat M. A. Salem
}

Department of Botany and Microbiology, Faculty of Science, Helwan University, Cairo, Egypt.

\begin{abstract}
The present study aimed to evaluating the effect of chloramphenicol (CAP) and copper $\left(\mathrm{CuSO}_{4}\right)$ on the cell ultra-structure of Scenedesmus sp. Three different concentrations of $\mathrm{CuSO}_{4}\left(10^{-3}, 10^{-4}, 10^{-5} \mathrm{M}\right)$ and two of CAP $(0.25$ and $0.5 \%)$ were added to exponentially growing algal culture $\left(10^{7} \mathrm{cells} \mathrm{ml}^{-1}\right)$ for $24 \mathrm{hrs}$. Cells treated with $10^{-3} \mathrm{M}$ CuSO4 and $0.5 \%$ chloramphenicol which gave high amount of cell lyses were chosen for examination by electron microscopy. Transmission electron microscopy photographs of Scenedesmus cells treated with $\mathrm{CuSO}_{4}$ showed deformation of the chloroplasts, while numerous vesicles were observed in the cytoplasm. The three-laminar sheath (TLS) and the reticulate layer (RL) had no differences in comparison with control. On the other hand, tubular spikelets had no distinct shape compared with the control. The inner layer of cell wall (cellulose layer) showed shrinkage in thickness. Moreover, cells treated with $0.5 \%$ CAP showed that chloroplast thylakoids were reduced in size and number, disorganization, shrinkage in all protoplasmic components and increasing in the number of vacuoles and cellulose layer thickness. These results may help in understanding the effect of some toxins such as antibiotics and heavy metals on the cell structure of microalgae.
\end{abstract}

\section{Key words}

Antibiotics, Cell Ultrastructure, Heavy Metals, Microalgae, Scenedesmus.

\section{Introduction}

Uptake of a metal into algal cells is considered to be a two-part process. Firstly, fast metal adsorption to sites on the exterior of the cell membrane occurs; and secondly the internalization of the metal across the cell membrane. It is hypothesized that metals internalization occurs via ion pores, channels or transporters in the algal cell membrane (Campbell, 1995 and Levy et al., 2007).

Anthropogenic water pollution products challenge to the survival of phytoplankton populations. The research on the effects of toxic wastes upon aquatic ecosystem has resulted in an extensive scientific literature which has given a quite useful; if not complete understanding on the subject Chloramphenicol (CAP) and copper sulphate $\left(\mathrm{CuSO}_{4}\right)$ represent toxic components for phytoplankton. 
The ultrastructure of the wall layers and ornamentative features of two Scenedesmus species were described using scanning electron micrographs by Staehelin and Pickett-Heaps (1975). Zbigrew and Jerzy (1995) illustrated the sensitivity of three Scenedesmus strains exposed to aqueous fuel-oil extract is strongly strain-dependent: $S$. quadricauda is the most resistant. S. armatus moderately tolerant whereas, the most sensitive appears to be $S$. microspina.

Chloramphenicol has a neutral $\mathrm{pH}$, so it is able to move freely through cell membranes and into vital organs, which makes it chemically flexible and able to attack a wide spectrum of bacteria, for that it is a powerful antibiotic against strong antibiotic-resistant bacterial strains. The eukaryotic cells, most likely to be inhibited by CAP are those undergoing rapid multiplication, thereby rapidly synthesizing mitochondria. Lai et al. (2009) investigated the growth inhibition effects of three phenicol antibiotics chloramphenicol, florfenicol, and thiamphenicol on Chlorella pyrenoidosa and two marine algae, Isochrysis galbana and Tetraselmis chui. They found that CAP was more toxic to Chlorella (EC50, $\left.14 \mathrm{mg} \mathrm{l}^{-1}\right)$ than florfenicol $\left(215 \mathrm{mg} \mathrm{l}^{-1}\right)$ and thiamphenicol (1283 $\left.\mathrm{mg} \mathrm{l}^{-1}\right)$.

On the other hand, copper like other trace elements, is required by plants and microorganisms as an essential micronutrient. However, at concentrations slightly higher than those required for growth, it becomes toxic to most life forms. The toxicity of copper to algae varies with environmental conditions (temperature, $\mathrm{pH}$, alkalinity, etc.), algal species or strain, physiological condition of the organism, culture medium and also with the copper forms (Schauber-Berigan $\boldsymbol{e t}$ al., 1993; Fargasová et al., 1999; Franklin et al., 2002).

The purpose of the present study was to identify changes in the fine structure of Scenedesmus cells as a result of exposure to chloramphenicol and copper sulphate treatments.

\section{Materials and Methods}

\section{Test organism and culture conditions}

Scenedesmus sp. (Chlorophyta) was selected as the test organism. It was isolated from the River Nile water, Egypt and cultured in the laboratory in BG 11 culture medium. The $\mathrm{pH}$ of the culture medium was adjusted to 7 using $\mathrm{NaOH}$ $\mathrm{HCl}(0.1 \mathrm{~N})$. The cultures were illuminated with fluorescent light giving $2600 \mathrm{Lux}$ for $16 \mathrm{~h}$ daily at $27 \pm 2^{\circ} \mathrm{C}$ for 31 days incubation period, this culture represent the control. 


\section{Experimental design}

Ten $\mathrm{ml}$ exponentially growing culture with cell number $10^{7} / \mathrm{ml}$ of Scenedesmus sp. was supplemented with $1 \mathrm{ml}$ of $10^{-3}, 10^{-4}$ and $10^{-5} \mathrm{M}$ of $\mathrm{Cu}$ from a freshly prepared stock solution of analytical grade $\mathrm{CuSO}_{4}$. Treatment with chloramphenicol takes place by adding $1 \mathrm{ml}$ of 0.25 or $0.5 \%$ CAP to $10 \mathrm{ml}$ of culture and the culture was incubated for $24 \mathrm{hrs}$ under the conditions described above. Thereafter, the cells were harvested by centrifugation at $3000 \mathrm{rpm}$ for about 20 minutes. The most effective concentrations $\left(10^{-3} \mathrm{M} \mathrm{CuSO}_{4}\right.$ and $0.5 \%$ chloramphenicol) on the algal culture, which change its color from dark green to yellowish green, were examined by electron microscopy.

\section{Transmission electron microscopy}

For electron microscopy, cells were fixed by immersion in $1 \%$ potassium permanganate solution, and then the fixed specimens were dehydrated through a graded ethanol series of 30,50,70, 90\% and finally absolute ethanol. The absolute alcohol was replaced by propylene oxide via a stepwise series of ethanol: propylene oxide 2:1, 1:1 and 1:2, and finally maintained in pure propylene oxide. Dehydrated specimens were embedded in an epoxy resin and stored in clean syringes at $4^{\circ} \mathrm{C}$ and allowed to attain room temperature before use. They were infiltrated with the resin mixture, embedded in pure resin for 1 hour at $40^{\circ} \mathrm{C}$ to get rid of any residual propylene oxide and the resin was polymerized at $60^{\circ} \mathrm{C}$ for 48 hours and then allowed to attain room temperature. The sections were double stained in uranyl acetate followed by lead citrate, (Reynolds, 1963). Stained sections $1 \mu \mathrm{m}$ thick, were examined with a JEOL 1010 Transmission Electron Microscope at the Regional Center for Mycology and Biotechnology (RCMB), Al-Azhar University, Cairo, Egypt.

\section{Results}

The general view of coenobium under light microscope showed that the population of Scendesmus sp. (Fig.1A) was composed of unicells, 2-celled coenobium and 4- celled coenobium.

Transmission electron microscopy (TEM) photographs showed that, at low magnification 15000× (Fig. 1B), control coenobium cell have typical organization; nucleus, cytoplasm and the cell wall which composed of normal inner and outer layers. The inner layer is amorphous cellulosic layer and the outer layer is connected firmly to the outer surface which composed of several sublayers including three -laminar sheath (TLS). 

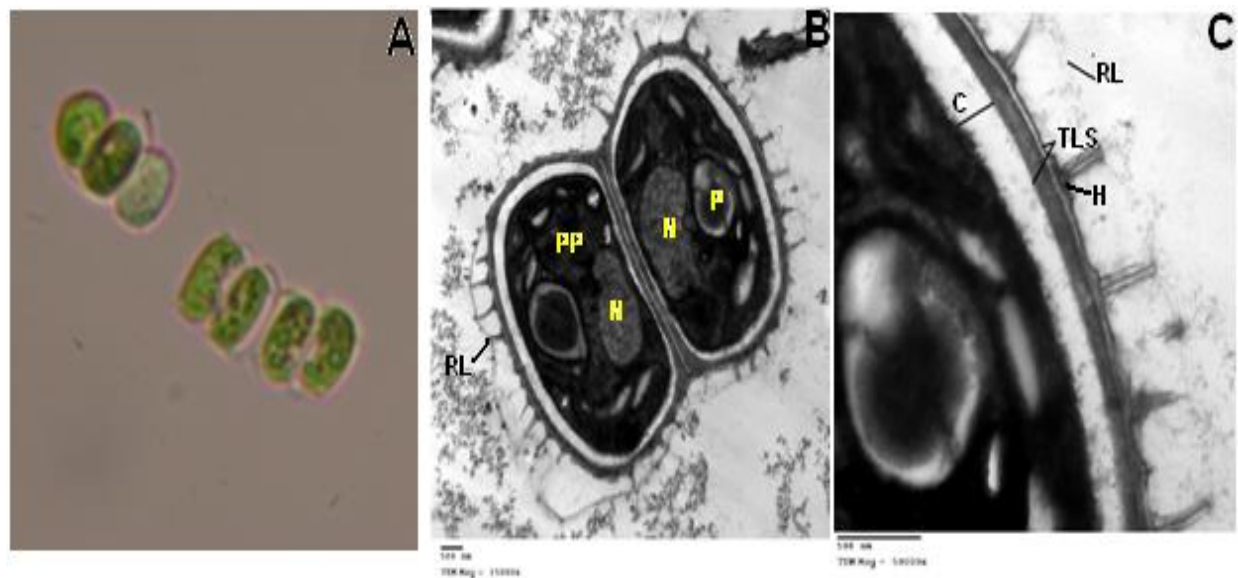

Figure (1): A) Light microscope view at 100× showing Scenedesmus sp. coenobium (control); B) Electron microscopy photo at 15000 $\times$ shows typical organization of control cell; $\mathbf{N}=$ Nucleous, $\mathbf{P}=\mathbf{P y r e n o i d s}, \mathrm{RL}=$ Reticulate layer, $\mathrm{PP}=$ poly phosphate bodies. C) Electron microscopy photo at $50000 \times$ shows the tubular spikelet, TLS= Three laminar sheath, $\mathbf{H}=$ Honey comb structure, $\mathbf{R L}=$ Reticulate layer and $\mathrm{C}=$ Cellulose layer

The whole coenobium was enclosed with a loosely fitting epistructures called reticulate layer (RL), spatially from three laminar sheath (TLS), it is supported by propping spikelets (arrows), the chloroplast have distinct thylakoids with one pyrenoid (P). Fig. (1C-50000x) showed the tubular spikelet and the cellulose layer $(\mathrm{C})$, with constant thickness all over the cell wall, honey comb structure $(\mathrm{H})$ is present and also some storage granules.

The present study showed that treatment with $0.5 \%$ chloramphenicol resulted in shrinkage of all protoplasmic components of the cell and increasing in number of vacuoles, while, spikelets were not appeared as tubular compared to the control (untreated culture)(Fig. 2 A and B).

The ultrastructure organization showed that the chloroplast was deformed detachment of the cell membrane from the cell wall was frequently observed in stressed cells, especially those going through necrosis of the space between the cell wall and the cell membrane (Fig. 2 A). The RL is still present and there is no change in cell wall structure. The accumulation of chloramphenicol takes place inside the protoplasm of the cell and away from the cell wall (Fig. 2 B). 

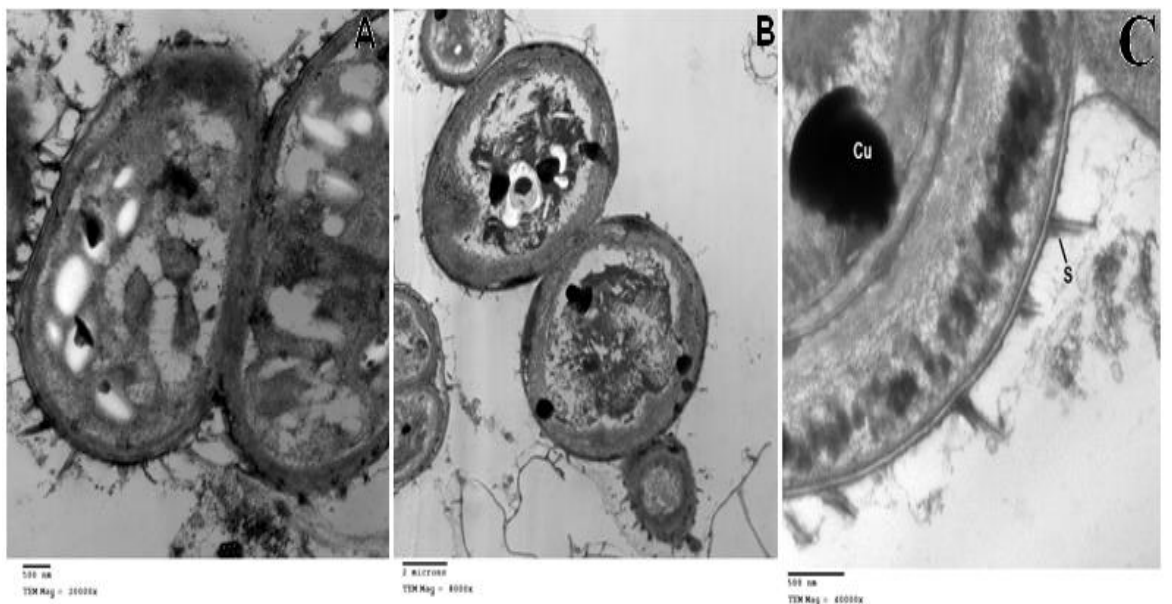

Figure (2): A) Electron microscopy photo at 12000× shows 0.5\% Chloramphenicol treated cells, the vacuolations and cell wall structure; $B$ ) Electron microscopy photo at $15000 \times$ shows no difference in cell wall and shrinkage of all protoplasmic components, and disorganization of chloroplast

Figure (3) shows the different effects of $\mathrm{Cu}$ treatment at concentration of $10^{-3} \mathrm{M}$, it illustrated that $\mathrm{CuSO}_{4}$ at this concentration increase the number of vacuoles as well as the thylakoids damage and the chloroplast deformation (Fig. 3A). Meanwhile, fig. (3B) illustrated that $\mathrm{Cu}$ accumulated inside the protoplasm of the cell and under the cell wall layers. Fig. (3 C magnification 40000x) showed that TLS layers and RL did not show differences in comparison to untreated culture. While, tubular spikelet have not distinct shaped such as control cell, the inner layer of cell wall (cellulose layer) showed shrinkage in thickness all over the cell wall. Apparent changes in cell ultrastructure after the uptake and internalization of copper were an increase in the number and size of vacuoles. 

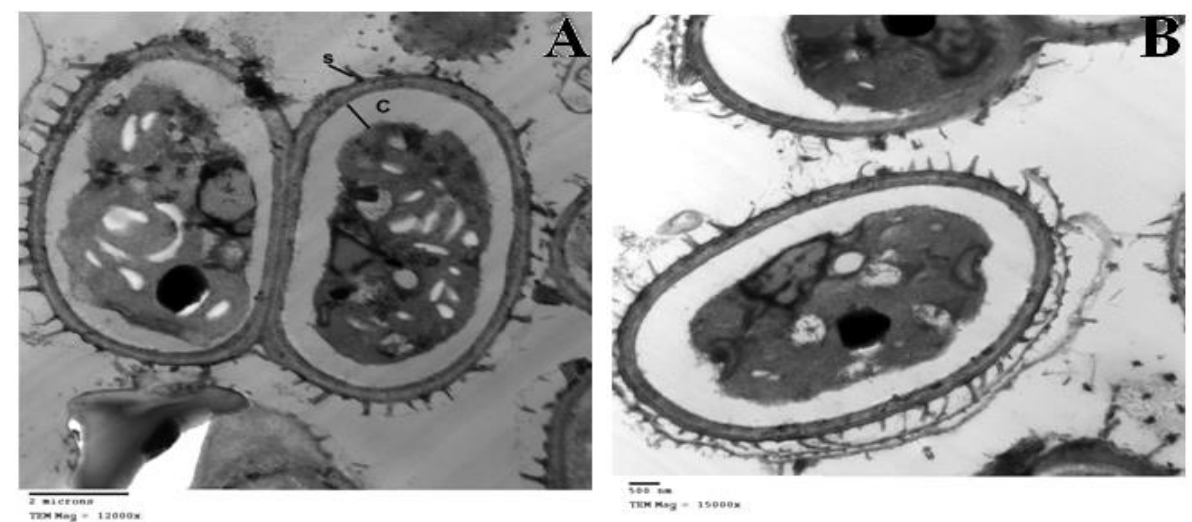

Figure (3): Copper sulphate treatments; A) Electron microscopy photo at 20000x shows vacuolations and damage in thylakoids at $10^{-3} \mathrm{M} \mathrm{CuSO}_{4} ; \mathrm{B}$ ) transverse section of the 4-celled coenobium at 8000x shows the sites of $\mathrm{Cu}$ accumulation, and $\mathrm{C}$ ) magnification at $40000 \times$ shows the changes in cell wall and epistructures and the spikelet (S)

\section{Discussion}

The two layers of cell wall observed in the study; cellulosic layer and TLS are present in different species of Scenedesmus. Zbigrew and Jerzy (1995) illustrated the cell wall structure of three Scenedesmus strains and found that the cell wall of these strains is built up of the two layers.

Taylor (1963) illustrated considerable difference between various organisms (Scenedesmus quadricauda, bacteria and Chlorella) and higher plant tissues in the concentration at which chloramphenicol inhibitions occur. Chloramphenicol acts as bacteriostatically and prevents the synthesis of proteins by binding onto ribosomes in the same place and mRNA binds to ribosomes. The response of Scenedesmus quadricauda occurred at the same concentration as for bacteria, while, higher plant tissues and Chlorella response is different. These differences might be due to differences in permeability to chloramphenicol which might operate through differences in the proteins or lipids of the plasma membrane, or be due to differences in the site of chloramphenicol binding.

Zhang et al. (2013) Illustrated that the growth and Chlorophyll-a syntheses of Scenedesmus obliquus were more sensitive in response to CAP exposure than that of Chlorella pyrenoidosa. The present results showed damage in thylakoids and chloroplast deformation these result agree with Smith- 
Johannsen and Gibbs (1972). They indicated that, in CAP-treated cells the total number of thylakoids per chloroplast section was markedly reduced. Since the chloroplasts of the CAP-treated cells relatively increased in size, there was also a marked reduction in thylakoid size in the drug-treated cells. Also, they illustrated that chloramphenicol, which selectively inhibits protein synthesis on organelle ribosomes' affect on the ultrastructure of the chloroplast and mitochondria of Ochromonas danica and also affect on the number and organization of internal organelle membranes during light-induced chloroplast development. Goran $\boldsymbol{e t}$ al . (2001) determined the effect of chloramphenicol in concentrations of 66, 100, and $250 \mathrm{mg} \mathrm{l}^{-1}$ upon the symbiosis between Hydra and Chlorella which lives inside the myoepithelial cells of gastroderm of Hydra, they observed changes in algal position, structure and ultrastructure, in some algae. The ultrastructure was completely destroyed with higher concentrations. Their chloroplasts, mitochondria and other organelles were completely destroyed. The detachment of the cell membrane from the cell wall might be due to the degradation products of cellular constituents, or simply some extracellular substances produced by cells because algae are known to increase the production of organic substances under stress, which filled the cellulosic layer (Maršalek and Rojıcková, 1996; Mishra and Jha, 2009).

Many of the ultra structural changes observed in this study after the uptake and internalization of copper were an increase in the number and size of vacuoles are similar to changes reported for heavy metal exposure (Levy et al., 2008). They demonstrated that Tetraselmis sp. and Dunaliella tertiolecta cells did not change in size, but had increased number of vacuoles with larger sized. Saçan et al. (2007) observed an increase in vacuolization and polyphosphate bodies in Dunaliella tertiolecta exposed to lead and aluminum and an over accumulation of starch. Scenedesmus sp. cells were a little more resistant to the presence of copper in solution but analogously were completely inhibited by the presence of copper at $4.5 \mathrm{mg} \mathrm{l}^{-1}$ (Amado et al., 2009). Slowik and Pawlaczyk-Szpilowa (1979) found that copper in the concentration of $1 \mathrm{mg} \mathrm{l}^{-1}$ caused the decrease of the total protein and the growth of the population as well as the destruction of histons, peptides chains and vacuolization of cells. Levy et al. (2008) and Salah El Din et al. (2009), found that neither visible deterioration nor damage to the outer plasmamembrane of treated cells. They noticed no damage to thylakoid membranes of the chloroplasts, while my results showed complete damage in the shape and organization of thylakoids. Nacorda et al. (2007) illustrated that ultrastructure alteration in the shape and organization of thylakoids affect on the photosynthetic apparatus. Chloroplasts and their arrangement represent a common target of toxic 
substances in algae and higher plants, dense bodies which occupied by electron microscopy representing opaque precipitates of $\mathrm{Cu}$ this agrees with Zhang $\boldsymbol{e t}$ al . (2002), which found that $\mathrm{Ni}$ accumulate by the same pattern as our conclusion on copper.

The results presented in this paper support the conclusion that $\mathrm{Cu}$ and CAP were toxic to some aquatic organisms in these concentrations and their effect on the cell concentrated on the effect on cell wall structure, and photosynthetic apparatus (chloroplast and thylakoids).

\section{References}

Amado, D. P.; Marini, C. B.; Gonçalves, M. M. M.A. and da Costa, A. C. A. (2009). Toxicidade e Bioacumulaçăo de Cobre por Microalgas dos Gêneros Monoraphidium sp. e Scenedesmus sp., Simpósio Nacional de Fermentações-SINAFERM, Natal, Brazil.

Campbell, P. G. C. (1995). Interactions between trace metals and aquatic organisms: A critique of the free-ion activity model. In: Tessier, A., Turner, D.R. (Eds.), Metal Speciation and Bioavailability in Aquatic Systems. John Wiley \& Sons Ltd, Chichester, England, pp. 45-102.

Fargasová, A.; Bumbalová, A. and Havranék, E. (1999). Ecotoxicological effects and uptake of metals $\left(\mathrm{Cu}^{+}, \mathrm{Cu}^{2+}, \mathrm{Mn}^{2+}, \mathrm{Mo}^{6+}, \mathrm{Ni}^{2+}\right.$ and $\mathrm{V}^{5+}$ ) in freshwater alga Scenedesmus quadricauda. Chemosphere, 38:1165-1173.

Franklin, N. M.; Stauber, J. L.; Apte, S. C. and Lim, R. P. (2002). Effect of initial cell density on the bioavailability and toxicity of copper in microalgal bioassays. Environ. Toxicol. Chem., 21:742-751.

Goran, K.; Mirjana, K.; Nikola, L. and Hrvojka, U. (2001). The effect of chloramphenicol on the symbiosis between alga and hydra. Biologia Bratislava, 56(6):605-610.

Lai, H. T.; Hou, J. H.; Su, C. I. and Chen, C. L. (2009). Effects of chloramphenicol, florfenicol, and thiamphenicol on growth of algae Chlorella pyrenoidosa, Isochrysis galbana and Tetraselmis chui. Ecotoxicol Environ. Saf., 72(2):329-334.

Levy, J. L.; Stauber, J. L. and Jolley, D. F. (2007). Sensitivity of marine microalgae to copper: the effect of biotic factors on copper adsorption and toxicity. Sci. Total. Environ., 387:141-154.

Levy, J.; Angel, B.; Stauber, J. L.; Poon, W. L.; Simpson, S. L.; Cheng, S. and Jolley, D. F. (2008). Uptake and internalisation of copper by

Egyptian J. of Phycol. Vol. 15, 2014 
three marine microalgae: comparison of copper-sensitive and copper-tolerant species. Aquatic Toxicology, 89:82-93.

Maršalek, B. and Rojıcková, R. (1996). Stress factors enhancing production of algal exudates: a potential self-protective mechanism? $Z$. Naturforsch., 51:646-650.

Mishra, A. and Jha, B. (2009). Isolation and characterization of extracellular polymeric substances from micro-algae Dunaliella salina under salt stress. Bioresource Technol., 100:3382-3386.

Nacorda, J. O.; Martinez-Goss, M. R.; Torreta, N. K. and Merca, F. E. (2007). Metal resistance and removal by two strains of the green alga, Chlorella vulgaris Beijerinck, isolated from Laguna de Bay, Philippines. J. Appl. Phycol., 19:701-710.

Reynolds, E. S. (1963).The use of lead citrate at high $\mathrm{pH}$ as an electron-opaque stain in electron microscopy. J. Cell Biol., 17(1): 208-212.

Saçan, M. T.; Oztay, F. and Bolkent, S. (2007). Exposure of Dunaliella tertiolecta to lead and aluminium: Toxicity and effects on ultrastructure. Biol. Trace. Elem. Res., 120:264-272.

Salah El Din, Rawheya A.; Gharib, Fatma A.; Ghazy, Safeya M. and Johny, E. Y. R. (2009). Effect of some heavy metals on growth of Scenedesmus obliquus (Turpin) Kützing. Egyptian Journal of Phycology, 10:23-36.

Schauber-Berigan, M. K.; Dierkes, J. R.; Monson, P. D. and Ankley, G. T. (1993). $\mathrm{pH}$ dependent toxicity of $\mathrm{Cd}, \mathrm{Cu}, \mathrm{Ni}, \mathrm{Pb}$ and $\mathrm{Zn}$ to Ceriodaphnia dubia, Pimephales promelas, Hyalella azteca and Lumbriculus variegatus. Environ. Toxicol. Chem., 12:1261-1266.

Słowik, J. and Pawlaczyk-Szpilowa, M. (1979). Interaction between Scenedesmus obliquus and the Heavy Metals Copper and Lead. Acta Hydrochimica et Hydrobiologica, 7(5):503-509.

Smith-Johannsen, Heidi and Gibbs, Sarah P. (1972) Effects of chloramphenicol on chloroplast and mitochondrial ulltrastructure in Ochromonas danica. The Journal of Cell Biology, 52:598-614.

Staehelin, L. A. and Pickett-Heaps, J. D. (1975). The ultrastructure of Scenedesmus (Chlorophyceae) species with the "reticulate" or "warty" type of ornamental layer. Journal of Phycology, 11(2):163-185.

Taylor, F. J. (1963). The Effect of Chloramphenicol on the Growth of Scenedesmus quadricauda. J . Gen. Microbiol., 39:275-284.

Zbigrew, T. and Jerzy B. (1995). Sensitivity to fuel oil and cell wall structure of some Scendesmus (Chlorococcales) strains. Acta Societatis Botanicorum Poloniae, 64(2):139-147. 
Zhang, W.; Sun, W.; An, S.; Xiong, B.; Lin, K.; Cui, X. and Guo, M. (2013). Acute and chronic toxic effects of chloramphenicol on Scenedesmus obliquus and Chlorella pyrenoidosa. Water Environ Res., 85(8):725-32.

Zhang-Li, H. U.; Yuk-Shan, W.; Fung-Yee, T. (2002). Bioaccumulation of Nickel by various Scenedesmus species in culture solution containing Nickel. Acta Botanica Sinica, 44(8):978-982.

\footnotetext{
تأثير الكلورامفينيكول والنحاس على التركيب الدقيق لخلية السنديسمس

ألفت معتمد عبد الحميد سالم

قسم النبات والميكروبيولوجى- كلية العلوم - جامعة حوان

تهدف الدراسة الحالية الى تقييم تأثير الكلورامفينيكول (CAP) و النحاس (فى صورة كبريتات

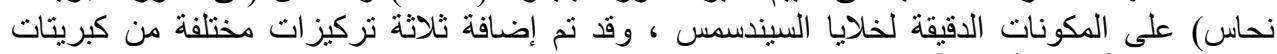

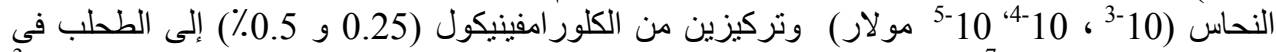

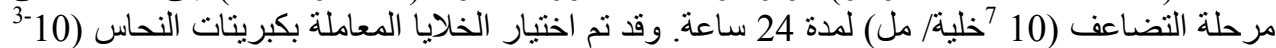

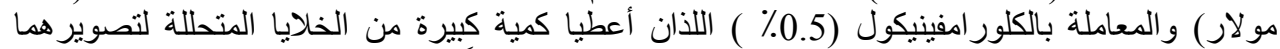

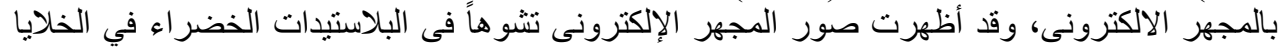

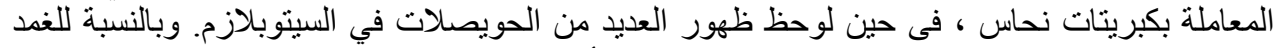

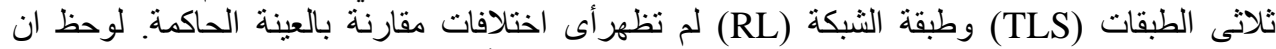

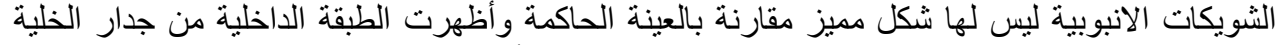

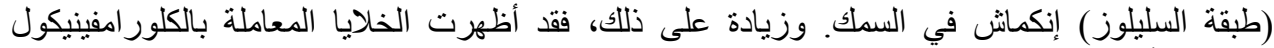

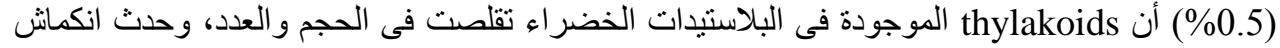

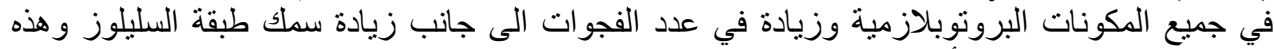

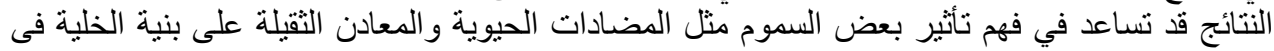

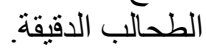

